\title{
FILOSOFIA COMO TAREFA
}

\author{
Philosophy as a task
}

\author{
Galileu Galilei Medeiros de Souza *
}

Resumo: $\mathrm{O}$ artigo tem como objetivo evidenciar o sentido da filosofia como tarefa e algumas consequências que disso advêm, como a superação de limitações epistemológicas relacionadas com a identificação entre conhecimento e reflexão, fundamento de teses sobre o fim da verdade. Toma-se como elemento norteador a filosofia da ação de Maurice Blondel, especialmente recorrendo aos dois escritos que compõem Le point de départ de la recherche philosophique (publicados em janeiro e junho de 1906). Adotando uma metodologia dialética, o presente texto parte do exame da questão da crise da razão e de sua ligação com a interpretação da reflexão como instrumento de conhecimento; são examinadas algumas hipóteses sobre o ponto de partida da filosofia, ligadas ao realismo, ao idealismo crítico e ao intuicionismo; atinge-se, enfim, a individuação do conhecimento em ato, que se mostra um processo de elucidação da prospecção pela reflexão, como o modo de conhecer próprio da pesquisa filosófica.

Palavras-chave: Prospecção. Reflexão. Conhecimento em ato. Filosofia.

Abstract: This paper aims to highlight the nature of philosophy as a task and show some resulting epistemological consequences, such as the overcoming of epistemological limitations related to the identification between knowledge and reflection, basis of theses on the end of truth. Maurice Blondel's work, the philosophy of action, will be our guiding element, especially his two writings making up Le point de départ de la recherche philosophique (published in January and June 1906). Using a dialectical methodology, this paper starts by examining the

\footnotetext{
* Doutor em filosofia pela Universidade Federal da Paraíba. Professor adjunto IV do Departamento de Filosofia da Universidade do Estado do Rio Grande do Norte - UERN. Artigo recebido em 02/11/2016 e aprovado para publicação em 18/07/2017.
} 
question of the crisis of reason and its connection with the interpretation of reflection as a tool of knowledge. It then examines some assumptions concerning the starting point of philosophy that are related to realism, critical idealism and intuitionism. Finally, it discusses the issue of individuation of knowledge as act which is a process of elucidating prospection through reflection, as the proper way of acquiring knowledge in philosophical research.

Keywords: Prospection. Reflection. Knowledge in Act. Philosophy.

\section{Considerações iniciais}

$\mathrm{A}$ recorrência de teses paradoxais sobre o fim da verdade é uma das características definidoras de nossa época. ${ }^{1}$ Não que narrativas dessa natureza sejam historicamente inusitadas, já que a filosofia sempre foi convocada a justificar-se como conhecimento e, assim, a falar de sua familiaridade com a verdade. Aponto, em outra direção, para o fato de que o específico do desafio de cultivá-la hoje está em lidar com o símbolo paradigmaticamente dominante de uma filosofia decadente (philosophia occidens) ${ }^{2}$, que ganhou corpo a partir da modernidade e que se define em sua característica essencial pelo uso de um tipo de pensar, reflexivo ${ }^{3}$, crivado de antinomias.

Alguns traços desse símbolo são muito provavelmente incontestáveis. Que o pensar reflexivo, em crise, contribua decisivamente para a constituição do modo próprio de conhecer filosófico ou de sua racionalidade parece fora de questão. Ademais, não há dúvidas de que diversas produções em que este pensar se concretizou ou se concretiza estejam plenas de antinomias.

\footnotetext{
${ }^{1}$ Nessa direção, afirma Franca D'Agostini (Breve Storia della Filosofia nel Novecento: L'anomalia Paradigmatica. Torino: Einaudi, 1999 p. 290): “(...) é evidente que um balanço fiel da experiência de verdade que caracteriza o mundo ocidental nesta específica fase (ou que se tornou evidente nesta fase) não pode esconder o paradoxo do fim da verdade. Isso significa que uma diversa lógica deve iniciar sua estrada (ou já a iniciou) no nosso pensar (...). A diversa lógica dentro da qual a última fase da metafísica se move nos sugeriria aceitar a natural recorrência das teses autorrefutativas das quais é já substanciado o nosso saber ocidental". ${ }^{2}$ Todas as traduções apresentadas de textos citados em sua publicação original nesse artigo são do seu autor.

${ }^{3}$ Pouco a pouco procuraremos esclarecer a noção de "pensar reflexivo". Por ora, será suficiente dizer que por essa expressão entendemos o momento específico da compreensão (ação significativa consciente) constituído pelo uso da linguagem e que tem como resultado a representação, diferenciada, por sua vez, conforme o tipo de semântica de que faz uso. Por exemplo, se essa é baseada no princípio da contextualidade sentencial ou no princípio de composicionalidade semântica (PUNTEL, Lorenz. A totalidade do Ser, O Absoluto e o tema "Deus": um capítulo de uma nova metafísica, 2007. In: IMAGUIRE, Guido; ALMEIDA, Custódio Luís S. de; OLIVEIRA, Manfredo Araújo de [Org.]. Metafísica contemporânea. Petrópolis, Vozes, 2007, p. 191 - 222.). Ademais, entenda-se neste texto pensar reflexivo como sinônimo de reflexão.
} 
Mas esses traços seriam características essenciais do pensar que envolve o exercício da filosofia?

Com essa pergunta, a presente investigação evidencia sua natureza e seus objetivos. Nela estão implícitos dois problemas: as antinomias são essenciais ao pensar reflexivo? E qualquer que seja a resposta a esta questão: $O$ exercício filosófico é inteiramente compreendido pelo pensar reflexivo?

Enfrentaremos nesse texto, eu e o leitor, apenas a segunda questão. Sob esta condição de estudo, o problema verdadeiro a ser examinado é saber se a filosofia, com seu modo próprio de conhecer, limita-se exclusivamente ao pensar reflexivo e à sua específica lógica, porque nesse caso seria preciso assumir que a eventual falência da reflexão equivaleria à falência da filosofia.

Procurando dar conta desse interrogativo, aproveitando da filosofia da ação e fazendo uso de uma metodologia fenomenológica e dialética ${ }^{4}$, recorreremos a alguns escritos de Maurice Blondel, especialmente aos dois artigos que compõem Le point de départ de la recherche philosophique ${ }^{5}$.

A exposição que segue versará inicialmente sobre o sentido do que seja "antinomia" e sua relação com a reflexão. Como em um sentido lato "antinomias" são simplesmente oposições e conflitos de qualquer natureza, aparentes ou reais, ${ }^{6}$ desde já, é preciso dizer que interessa a essa investigação apenas considerar aquelas relacionadas com a justificação do pensar reflexivo. Posteriormente, procurarei mostrar, descortinando o ponto de partida da filosofia, a natureza do pensar que a caracteriza.

\footnotetext{
${ }^{4}$ Dialética aqui no sentido em que esta é entendida por Aristóteles (Tópicos, 100a18-22): “um método que nos capacite a raciocinar, a partir de opiniões de aceitação geral, acerca de qualquer problema que se apresente diante de nós e nos habilite, na sustentação de um argumento, a nos esquivar da enunciação de qualquer coisa que o contrarie". Esse entendimento aristotélico é muito semelhante ao que Platão enuncia na República, ou seja, da dialética como modo de conhecer que parte do estudo de hipóteses para identificar o que implicitamente nelas não admite hipótese, porque é seu princípio necessário, outro em relação às hipóteses e à dialética: "Aprende então o que quero dizer com o outro seguimento do inteligível, daquele que o raciocínio atinge pelo poder da dialéctica, fazendo as hipóteses não princípios, mas hipóteses de facto, uma espécie de degraus e de pontos de apoio, para ir até àquilo que não admite hipóteses, que é o princípio de tudo [...]" (República, 511b).

${ }^{5}$ Publicado pela primeira vez nos Annales de Philosophie Chrétienne sob a forma de dois artigos (janeiro e junho de 1906), a razão imediata desse escrito é o desejo de Blondel de responder às acusações de irracionalismo a que sua filosofia fora sujeita ao propor a ação como fim da especulação - como se observa, por exemplo, na Action (1893). A partir de agora nos remeteremos a este escrito simplesmente como Le point de départ.

${ }^{6}$ Cf. LALAND, André (Org.). Vocabulaiere téchnique et critique de la philosophie (1902-1923). Paris, PUF, 1926. Tradução portuguesa de Fátima Sá Correia, Maria Ermínia Aguiar, José Eduardo Torres e Maria Gorete de Souza: Vocabulário Técnico e Crítico da Filosofia. São Paulo: Martins Fontes, 1999, p. 72.
} 


\section{As antinomias do pensar reflexivo}

Considerando os pressupostos apontados anteriormente, as antinomias que devem ser objetos de nossa atenção são aquelas que se descobrem quando da consideração do alcance exclusivamente racional do pensar reflexivo, tradicionalmente vinculado à filosofia. Assim entendida, a antinomia surge quando o pensar reflexivo não pode justificar adequadamente de modo racional a sua escolha entre teorias explicativas que se apresentam, ao menos aparentemente, como opostas ou até contraditórias.

Ademais, um outro cuidado inicial é incontornável: devemos renunciar a elencar exaustivamente todas as antinomias resultantes desse exercício reflexivo. Primeiramente porque isso seria uma tarefa impossível, já que antinomias podem surgir a cada nova solução teórica proposta, a cada nova tentativa de reforma filosófica do pensar reflexivo; mas principalmente porque não importa tanto observar cada antinomia singularmente considerada, quanto as condições que sustentam todas elas.

O estudo dos escritos blondelianos é significativo a esse respeito. Em sua filosofia, Blondel dá conta explicitamente não só da presença de antinomias no seio da reflexão, como também de suas condições. Por exemplo, em Principe élémentaire ${ }^{7}$, ele partirá da constatação de uma antinomia já tradicional para o pensar ocidental, a saber, a da contraposição entre a moral (orientação do agir humano voluntário) e a lógica. Nesse texto, ${ }^{8}$ afirma-se que o anseio por uma lógica da vida moral ou por uma moral científica, já enunciado por Leibniz como uma esperança e um desejo, pareceu ser sempre um projeto contraditório. Se, por um lado, a ciência exige rigor e necessidade lógica, por outro, a ação moral ou a vivência da vida boa pressupõe contingência e liberdade.

Sem dúvida, em razão de elementos e influxos culturais - como a valorização do exercício histórico da solidariedade entre os homens ou a influência educativa da literatura e da arte - , desenvolveu-se nas culturas ocidentais um certo sentimento de uma lógica ou de uma justiça imanente à vida. Sem dúvida, ainda, a filosofia fez um imenso esforço para tematizar não só a riqueza inexaurível do espírito, mas também a das coisas, e para "reivindicar a independência ou defender a supremacia da vida moral contra a tirania das palavras e a usurpação dos conceitos" .

\footnotetext{
${ }^{7}$ Texto que corresponde ao memorial apresentado por Maurice Blondel quando do Congresso Internacional de Filosofia em Paris no ano de 1900. O título completo é Principe élémentaire d'une logique de la vie morale. Nos remeteremos a ele simplesmente como Principe élémentaire. ${ }^{8}$ BLONDEL, Maurice. "Principe élémentaire d'une logique de la vie morale". In:

Ouvres complètes II: 1888-1913. La philosophie de L'Action et la crise moderniste. Paris: PUF, 1997c, p. 365-385.

${ }^{9}$ BLONDEL, Maurice. "Principe élémentaire d'une logique de la vie morale". In: Ouvres complètes II: 1888-1913. La philosophie de L'Action et la crise moderniste. Paris: PUF, 1997c, p. 367.
} 
Todavia, a reflexão aí desenvolvida "Ou limitou-se a subordinar tanto quanto possível o real ao racional e a vida ou a história mesma à dialética idealista, ou a opor a ordem prática e moral com seu gênero próprio de certeza e suas leis autônomas à ordem especulativa ou científica e às normas do pensar"10. Assim, um dualismo entre essas duas ordens e suas dialéticas foi sempre alimentado, interpretando-as como incomensuráveis e sacrificando uma à outra.

Mas, e é o que constitui o paradoxo do problema, vida e pensar são inseparáveis: "nem o pensar é o pensar sem a vida, nem a vida é a vida sem o pensar. (...) viver é realizar a unidade entre pensamento e ação"11.

Outros exemplos de antinomias como essa se multiplicam nos escritos de Blondel. Em L'Illusion idéaliste, por exemplo, a antinomia enfrentada diz respeito à oposição entre realismo e idealismo crítico $^{12}$ como formas contrapostas e exclusivas de conhecimento. Para o realismo, o conhecimento seria uma representação adequada das coisas tal e qual são em si mesmas. Para o idealismo em sua apresentação crítica, o conhecimento seria uma produção subjetiva, sendo a coisa em si, objetiva, inatingível:

Por um primeiro movimento, somos levados a tomar nossas representações imediatas como a verdadeira verdade. Por um segundo movimento, inseparável do primeiro, somos forçados a procurar sempre, além do que parece diretamente presente à consciência, e abaixo, atrás ou dentro do real, um real mais real ainda. Se o apetite realista, para não ficar sem alimento, teme tomar o ser pelo fenômeno, o desejo idealista, para não festejar grosseiramente, teme tomar o fenômeno pelo ser. ${ }^{13}$

Aparentemente, realismo e idealismo (crítico) seriam contraditórios: se um é verdadeiro, o outro é falso. Essa aparência, contudo, é muito frágil: "é impossível tanto definir, quanto escolher efetivamente qualquer uma dessas duas atitudes excluindo a outra"14. De fato, a atitude

${ }^{10}$ BLONDEL, Maurice. "Principe élémentaire d'une logique de la vie morale". In: Ouvres complètes II: 1888-1913. La philosophie de L'Action et la crise moderniste. Paris: PUF, 1997c, p. 367-368.

${ }^{11}$ BLONDEL, Maurice. "Principe élémentaire d'une logique de la vie morale". In:

Ouvres complètes II: 1888-1913. La philosophie de L'Action et la crise moderniste. Paris: PUF, 1997c, p. 368.

${ }^{12}$ É preciso sublinhar que estamos falando aqui de idealismo crítico e não de idealismo absoluto, cuja filosofia paradigmática é a hegeliana. Hegel se propõe a mesma dificuldade que se discute em L'illusion idéaliste, a saber, a que versa sobre a oposição entre realismo e idealismo crítico. Entretanto, suas conclusões são completamente outras. Assumindo os resultados do idealismo crítico, Hegel, porém, vai mais longe e não teme tomar o fenômeno pelo ser. A contraposição entre reflexão e realidade é superada por um monismo para o qual, em última análise, elas se identificam e se confundem. Veja-se como exemplo a monumental Fenomenologia do Espírito.

${ }^{13}$ BLONDEL, Maurice. "L'Illusion idéaliste" (1898). In: Ouvres Completes II, 1888-1913. La philosophie de L'Action et la crise moderniste. Paris: PUF, 1997b, p. 197.

${ }_{14}$ BLONDEL, Maurice. "L'Illusion idéaliste" (1898). In: Ouvres Completes II, 1888-1913. La philosophie de L'Action et la crise moderniste. Paris: PUF, 1997b, p. 197. 
realista e aquela idealista são solidárias, sendo igualmente fundadas e inconsistentes:

Inconsistentes, na medida em que a reflexão reduz artificialmente, sem lhes restringir a suas fórmulas, os movimentos da dialética em ato. Fundadas, no sentido de que elas se impõem à consciência, que elas constituem um momento do determinismo interno e um recurso do dinamismo da vida espiritual. ${ }^{15}$

Por sua vez, em Le point de départ, uma antinomia é reconhecida no que concerne ao processo de gênesis da filosofia: essa estaria em estreita ligação com o pensar comum e com os problemas normais da vida cotidiana, sendo sua sistematização e dizendo respeito a todo homem, ou, na verdade, a filosofia seria um pensar autônomo em relação ao senso comum e à vida concreta, existindo apenas no interior dos sistemas filosóficos, como um pensar "especializado" e "setorizado"? Em uma linguagem mais contemporânea, a filosofia seria a sentinela dos discursos significativos em geral ou apenas um jogo linguístico entre outros?

Por um lado, é comum atribuir a adjetivação de "filosóficas" a numerosas considerações voltadas a interesses gerais e vivenciais dos homens, que supõem até certa penetração de espírito, mesmo sem que isso signifique a superação de uma atenção mais fragmentária. Por outro lado, os filósofos no sentido forte do termo, os profissionais, tendem a revestir seu pensamento de uma forma sistemática e a conduzir a discussão sobre a universalidade dos problemas a uma unidade de uma doutrina tecnicamente específica. É a partir dessas filosofias específicas que se puderam produzir e desenvolver as principais aquisições interpretativas ou verdades do patrimônio filosófico comum, que depois se transformam em verdades independentes, sendo inclusive incorporadas por outros sistemas, de tal modo que se pode dizer que a filosofia não existe senão como "sistemas filosóficos", heterogêneos e especializados, ainda que interdependentes.

Desse modo, na história geral do pensamento humano, como na de cada doutrina particular, parece que se dá uma passagem insensível da reflexão banal à sistematização técnica e, ao mesmo tempo, que não existe nada de propriamente filosófico senão as verdades nascidas e desenvolvidas no seio de um organismo científico, totalizante e absorvente, "onde a ideia do conjunto faz a força e a fecundidade das partes"16.

Por pouco que se reflita sobre essa anomalia, uma antinomia logo se apresenta, como se houvesse um desacordo inevitável entre a matéria e

\footnotetext{
${ }^{15}$ BLONDEL, Maurice. “L'Illusion idéaliste" (1898). In: . Ouvres Completes II, 1888-1913. La philosophie de L'Action et la crise moderniste. Paris: PUF, 1997b, p. 197. (BLONDEL, $1997 b$, p. 197.

${ }^{16}$ BLONDEL, Maurice. "Le point de départ de la recherche Philosophique" (1906). In:

Ouvres Complètes II, 1888-1913. La philosophie de L'Action et la crise moderniste. Paris: PUF, 1997a, p. 529.
} 
a forma da filosofia. De uma parte, a filosofia pretendeu sempre exercer uma jurisdição universal, ou seja, não tudo conhecer, mas, sem dúvida, conhecer de tudo, ter competência para se pronunciar sobre tudo. De outra, a filosofia parece tender cada vez mais a se especializar como uma forma de saber à parte, de modo que, diferentemente das outras ciências, que tendem a adaptar seus métodos particulares aos seus objetos, a filosofia parece se inclinar a adaptar o objeto universal do qual ela se ocupa a seus métodos particulares, "que sobre a cobertura das formas impessoais de uma disciplina técnica, exprimem as singularidades de suas preferências intelectuais ou de suas experiências morais"17. Enfim, enquanto a filosofia encontra sua matéria no movimento geral da vida espiritual da humanidade, por sua forma parece obrigada a se contentar com os diversos sistemas particulares "sem que sua apresentação, para a qual ela aspira por conseguir uma precisão técnica, possa jamais tomar uma caracterização científica, coletiva, perfectível pelo esforço acumulado"18.

Assim, pensamento e ação, realismo e idealismo, universalidade e perspectividade do discurso filosófico. Passadas em revista essas três antinomias, podemos dar outro passo, na direção de colher uma sua caracterização comum.

Ainda que diversas, as antinomias da reflexão, aqui só exemplificadas, estão sempre vinculadas a uma precisa noção de conhecimento que lhes dá sustentação: a que comporta uma dualidade fundamental entre ser e pensar. A esse respeito, em L'Illusion idéaliste, esclarece Blondel:

[...] no momento em que se atribui ao dado um valor real, afirmando o que é naquilo que aparece, já por esse ato mesmo se põe diante do pensar a dualidade entre o real e o conhecido, daí a coincidência ou desigualdades concebíveis, daí ainda a afirmação ou a negação de uma adequação possível de um com o outro. ${ }^{19}$

De modo semelhante, retoricamente Blondel se perguntará em Le point de départ sobre se não seria possível conceber ou, melhor ainda, realizar uma doutrina onde a matéria universal da filosofia e sua forma específica se correspondessem, de tal modo que não só a pesquisa filosófica estivesse em perfeito acordo e continuidade com o movimento da vida, mas ainda: "seria essa vida mesma enquanto ela se enche de luz e de realidade e enquanto ela se subordina expressamente às condições das quais depende

\footnotetext{
${ }^{17}$ BLONDEL, Maurice. "Le point de départ de la recherche Philosophique" (1906). In: Ouvres Complètes II, 1888-1913. La philosophie de L'Action et la crise moderniste. Paris: PUF, 1997a, p. 530.

${ }^{18}$ BLONDEL, Maurice. "Le point de départ de la recherche Philosophique" (1906). In: Ouvres Complètes II, 1888-1913. La philosophie de L'Action et la crise moderniste. Paris: PUF, 1997 a, p. 530.

${ }^{19}$ BLONDEL, Maurice. “L'Illusion idéaliste” (1898). In: Ouvres Completes II, 1888-1913.

La philosophie de L'Action et la crise moderniste. Paris: PUF, 1997b, p. 197.
} 
a solução efetiva do problema de nosso destino" ${ }^{20}$. No mesmo sentido, em Principe élémentaire, Blondel falará de uma lógica da atividade moral e intelectual - lógica da vida moral ou prática - , fundamento não só da ciência da prática, mas de qualquer outra ciência e da própria lógica formal, porquanto única capaz de medir o que o conhecimento possui de "verdade ontológica e lógica" 21 .

Em síntese, a hipótese que aí se configura é a de que a raiz de todas as antinomias da reflexão não é necessariamente ligada à essência do pensar reflexivo, mas a um modo específico de entendê-lo, fazendo-o o "tudo" do conhecimento. As antinomias se constituem como tais somente enquanto sustentadas por uma interpretação segundo a qual se dá uma dualidade entre o conhecimento e o real concreto, entre pensar e ser, porque a dualidade existe entre a reflexão e o real. Todavia, seria possível superar esse dualismo sem sacrificar um ao outro os dois termos dessa equação?

\section{O redimensionamento da reflexão}

Se me fosse solicitado resumir a grande intuição da filosofia blondeliana em uma frase, ela seria esta, colhida na versão de L'Illusion idéaliste: "A vida e o conhecimento da vida são coisas distintas" ${ }^{22}$. Porém, retirada de seu contexto, essa afirmação pode ser interpretada de modo oposto ao espírito blondeliano, como se indicasse um dualismo insuperável entre subjetividade e objetividade.

Para a filosofia da ação, embora distintas, a vida ou a ação/ser e o conhecimento da vida não se relacionam segundo uma lógica de oposição. A superação, sem confusão, do dualismo entre conhecer/pensar e ser/viver, tendo em vista uma colaboração fecunda entre eles, é a meta dessa filosofia.

\footnotetext{
${ }^{20}$ BLONDEL, Maurice. "Le point de départ de la recherche Philosophique" (1906). In: Ouvres Complètes II, 1888-1913. La philosophie de L'Action et la crise moderniste. Paris: PUF, 1997a, p. 530.

${ }^{21}$ BLONDEL, Maurice. "Principe élémentaire d'une logique de la vie morale". In:

Ouvres complètes II: 1888-1913. La philosophie de L'Action et la crise moderniste. Paris: PUF, 1997c, p. 376.

22 BLONDEL, Maurice. “L'Illusion idéaliste" (1898). In: Ouvres Completes II, 18881913. La philosophie de L'Action et la crise moderniste. Paris: PUF, 1997b, p. 210. Foi o que afirmara Léon Brunschvigc, concordando com Blondel a respeito de que a ideia da ação é diversa da ação, embora em descordo no que concerne à hierarquização entre a ação e sua ideia: "Pode-se admitir, com M. Blondel, que o idealismo, suficiente talvez para resolver os problemas da teoria, é condenado pelas exigências da ação? A ação é outra coisa que a ideia da ação. Mas, uma ação humana, enquanto humana, deve seu caráter e seu valor à ideia da qual ela emana e que ela exprime" (BRUNSCHVIGC, Léon. "L'idéalisme contemporain". In: BLONDEL, Maurice. "Participation au premier congrès international de philosophie". In: _. Ouvres complètes II: 1888-1913. La philosophie de L'Action et la crise moderniste.
} Paris: PUF, 1997e, p. 313). 
Sem prescindir do recurso a outros textos, investigaremos agora a questão que diz respeito à superação desse dualismo a partir do fio condutor que nos oferecem os dois artigos que compõem Le point de départ. Isso nos permitirá um redimensionamento do sentido da reflexão, que será uma condição essencial para que essa superação seja possibilitada.

\section{Problematização Inicial sobre o Estatuto Científico da Filosofia}

Um primeiro olhar sobre a problematização da questão do dualismo entre ação e conhecimento apresentado em Le point de départ nos dá acesso a uma antinomia, já evidenciada há pouco. Basicamente, essa antinomia diz respeito ao estatuto científico ${ }^{23}$ da filosofia, o que não será uma discussão periférica nesse escrito. Ao contrário, ele constitui-se em um testamento valioso da interpretação blondeliana sobre a natureza da filosofia como programa de conhecimento - "científico".

O questionamento que lhe dá o primeiro fôlego será o seguinte: existiria um modo de conhecer próprio à filosofia, caracterizado por um específico ponto de partida, por uma específica meta e por um específico método, que a distinguiria de toda outra forma de conhecimento e, ao mesmo tempo, conservaria sua cientificidade e relevância? Há condições para se falar de uma filosofia que é, ao mesmo tempo, um modo de conhecer científico, especializado e universalmente relevante ou, ao contrário, ela deveria renunciar a essas pretensões, pelo menos, a essas pretensões conjuntamente consideradas?

Posta a questão, Blondel se alvitra à exposição e à justificação de duas teses interdependentes: a) a de que o conhecimento filosófico possui uma especificidade própria ou uma característica formal (racionalidade), expressa em suas exigências técnicas (metodologia), que determina de modo decisivo o início e a meta de sua pesquisa; b) a de que é somente por passar por essas exigências técnicas que o conhecimento filosófico pode fazer obra de ciência e de vida ao mesmo tempo.

A fim de desenvolver essas teses, inicialmente Blondel se proporá, em um processo dialético, à análise dos erros e dos falsos caminhos de resposta à questão sobre a natureza própria do conhecimento filosófico, para, fazendo uso dessa estratégia, mostrar que solução se impõe.

Nessa direção, três hipóteses são estudadas. Para a primeira hipótese, pressupondo-se a dissolução da realidade nas ideias, a filosofia partiria de uma reflexão isolada capaz de representar adequadamente o ser (hipótese

${ }^{23}$ Para a filosofia blondeliana, a noção de "ciência" designa tipos diversos de conhecimentos, não sendo limitada à ciência positiva. 
realista). Para a segunda, pressupondo-se a dicotomia insuperável entre conhecimento teórico e prática (ação concreta), a filosofia consistiria apenas em uma atitude crítica, devendo renunciar a qualquer juízo sobre a realidade (a hipótese do criticismo kantiano). Nessa acepção, a filosofia não teria como fim representar o real, mas velar a fim de que a reflexão seja aplicada apenas dentro de seus devidos limites ou, em outros termos, a filosofia seria a reflexão aplicada em vigiar a si mesma. Por fim, de acordo com uma terceira hipótese, a filosofia deveria partir de um conhecimento puramente intuitivo, direto e imediato (hipótese intuicionista, assumida pelo bergsonismo), no qual encontrará também sua realização. Esse conhecimento será chamado por Blondel de prospeç̧ão.

Para entender em que consiste a insuficiência de cada uma destas hipóteses, será útil, antecipadamente, precisar as noções de reflexão e de prospecção.

\section{As Noções de Reflexão e Prospecção}

O esclarecimento da distinção entre prospecção e reflexão será apenas o passo inicial para se entender o verdadeiro sentido da relação entre especulação e prática, pensar e vida. É preciso determinar tal sentido evitando incorrer no risco de ser refém de uma interpretação que não supere a simples lógica da oposição entre tais noções. Uma observação atenta simplesmente às diferenças entre especulação e prática (ação), sem colher o vínculo relacional que as une, como mostrarei a seguir, não é suficiente para defini-las convenientemente. E esse vínculo encontra-se na ação, na dinâmica relação, por ela possibilitada, que se desenvolve entre prospecção e reflexão.

O esforço por oferecer uma significação adequada a respeito do pensar e da vida deverá assumir como tarefa não só distinguir a ação e a ideia da ação, como também revelar o verdadeiro sentido do conhecimento prático, diferenciando-o da ideia que dele possuímos, evitando entender a prospecção com uma reflexão. Para superar o dualismo entre pensamento e vida, será preciso, primeiramente, suplantar o monismo que submete a ação à tirania dos conceitos e da lógica reflexiva. Bem compreendido, o conhecimento prospectivo oferecerá o terreno de passagem entre a prática e a especulação, a vida e a reflexão.

Isso observado, precisemos o sentido da reflexão e da prospecção. Enquanto a reflexão é o pensar (compreensão) em sua representação conceitual, a prospecção é o pensar (compreensão) que acompanha a ação e dela é inseparável, o que se pode chamar verdadeiramente de "intuição prática"24.

${ }^{24}$ BLONDEL, Maurice. "Le point de départ de la recherche Philosophique" (1906). In:

Ouvres Complètes II, 1888-1913. La philosophie de L'Action et la crise moderniste. Paris: PUF, 1997a, p. 534. 
O objeto da atenção da prospecção é a realização da ação. Na prospecção se resume em um ato, que aparece ao agente como relativamente simples, um grande número de experiências passadas, sintetizadas a partir do influxo de um grande número de ideias e movimentos projetados em direção ao futuro. Desse modo, ela volta-se permanentemente para a realização da ação concreta, para a "realização de um equilíbrio sempre ulterior" superando sem cessar o já realizado em direção da consumação da ação. É por isso que Blondel a chamará também de conhecimento ad usum ou conhecimento ad summum. A prospecção é um conhecimento que se realiza sob a luz da ação consumada, ou melhor, do projeto (futuro) da ação consumada. Ela constitui o fundo mesmo da atividade racional, ainda que não seja propriamente uma ação refletida.

Enquanto a reflexão é um conhecimento do já atuado, de tal modo que é uma ação significativa que tem como fim reapresentar, a prospecção é um conhecimento agente, voltado para a realização da ação, que acompanha a ação em seu fieri, em sua presença dinâmica, antecipando aí seu futuro, o que a ação deve ser. Enquanto a reflexão se aplica na análise retrospectiva do que a memória guarda da prática já vivida e na tentativa de sua tradução ou representação conceitual, sendo portanto um conhecimento retrospectivo, a prospecção toma a própria ação particular, sua concretude, seu fieri orientado projetualmente como objetos de atenção. Na prospecção o conhecimento escapa a categorias lógicas e classificações científicas em razão do que ela possui de único e inefável em cada agente. Em suma, usando de uma nomenclatura cuja estrutura será cara à filosofia da ação, o conhecimento prospectivo é essencialmente prático: "connaissance connaissante et agissante" 26 .

A prospecção constitui um procedimento sintético (conhecimento sintético), de modo que "resume as experiências passadas em uma antecipação que

${ }^{25}$ BLONDEL, Maurice. "Le point de départ de la recherche Philosophique" (1906). In: Ouvres Complètes II, 1888-1913. La philosophie de L'Action et la crise moderniste. Paris: PUF, 1997a, p. 532.

${ }^{26}$ BLONDEL, Maurice. "Le point de départ de la recherche Philosophique" (1906). In: Ouvres Complètes II, 1888-1913. La philosophie de L'Action et la crise moderniste. Paris: PUF, 1997a, p. 534. Preferimos conservar o texto no original, mas sua tradução portuguesa seria: "conhecimento cognoscente e atuante". Em diversos textos, Blondel utiliza da distinção entre o particípio presente e o particípio passado, para diferenciar a iniciativa primeira de uma síntese ativa (origem) do seu produto (obra). Assim, entre outros, diferenciam-se no pensar em ato um pensar pensante (origem) de um pensar pensado (obra); na vontade em ato, uma vontade querente ou volente (origem) de uma vontade querida (obra) e, como se pode antevê pela expressão reportada acima, no conhecimento em ato, um conhecimento cognoscente e atuante (origem) de um conhecimento conhecido e atuado (obra). Por exemplo, sobre a distinção entre vontade volente e vontade querida, afirma Blondel: "propondo-se a liberdade como um fim, sente-se a desproporção entre a vontade volente, quod procedit ex voluntate, e a vontade querida, quod voluntatis objectum fit" (BLONDEL, Maurice. L'Action: essai d'une critique de la vie et d'une science de la pratique (1893). Paris: Quadrige 1993, p. 132). 
é a causa implícita, mas real e sempre singular de seu desenvolvimento atual" ${ }^{\prime 2}$. Mas se dá também sob o influxo das razões singulares e concretas (não genéricas) do ato que se realiza, incluindo aqui as expectativas futuras. Por isso ela pode-se dizer um conhecimento sintético. Na reflexão, por sua vez, o ato é estudado como um fenômeno ou fato submetido a análises, que o dividem em partes suscetíveis de serem conhecidas e realizadas separadamente, sendo, portanto, um conhecimento de procedimento analítico:

[...] às razões verdadeiramente decisivas e singulares do ato que ela estuda se substituem as análises que dividem o fato em objetos suscetíveis de serem conhecidos e realizados isoladamente. Ela os examina, a esses objetos, no que eles têm de genérico, como se eles fossem absolutos, necessariamente justapostos e exteriores uns aos outros. E desde então suas causas, seu ser parece não mais dizer respeito ao que possuem de próprio ou de único em suas relações com a realidade singular de onde a reflexão os extraiu, mas residir em uma ideia genérica que lhe seria comum, ideia de causa que substitui a finalidade inteiramente singular que colocou em movimento minha ação. ${ }^{28}$

Enfim, como afirma Blondel, fazendo referência ao grande problema epistemológico que Aristóteles e sua metafísica nos deixou como herança: "Enquanto a prospecção se orienta em direção ao individuum ineffabile, a reflexão tende em direção ao ens generalissimum" ${ }^{\prime 29}$. O que concluir a partir dessas distinções?

Se tudo o que se pudesse afirmar a respeito da prospecção e da reflexão convergisse apenas para o que acabamos de expor, não teríamos remédio senão pensá-las segundo uma lógica opositiva. Como modos de conhecer, reflexão e prospecção seriam, de certa forma, antitéticos. Para salvar a relevância de uma, seria preciso sacrificar as pretensões da outra.

Todavia, considerando mais atentamente, e de modo fenomenológico, as coisas não estão assim. A condenação de uma, ao contrário, acarretaria igual destino para a outra. Sem a reflexão, a prospecção seria condenada à inconsciência e sem a prospecção a reflexão não poderia pretender para si a mínima justificação. Por um lado, ainda que a prospecção consista em pôr-se ativamente no real e concreto da ação, sem a reflexão seria impossível qualquer percepção dessa presença. Por outro, ainda que nem mesmo na prospecção se possa apreender o individuum ineffabile em toda a

\footnotetext{
${ }^{27}$ BLONDEL, Maurice. “Le point de départ de la recherche Philosophique" (1906). In: Ouvres Complètes II, 1888-1913. La philosophie de L'Action et la crise moderniste. Paris: PUF, 1997a, p. 535.

${ }^{28}$ BLONDEL, Maurice. "Le point de départ de la recherche Philosophique" (1906). In:

Ouvres Complètes II, 1888-1913. La philosophie de L'Action et la crise moderniste. Paris: PUF, 1997a, p. 535.

${ }^{29}$ BLONDEL, Maurice. "Le point de départ de la recherche Philosophique" (1906). In: Ouvres Complètes II, 1888-1913. La philosophie de L'Action et la crise moderniste. Paris: PUF, 1997a, p. 535.
} 
sua riqueza $-\mathrm{e}$, ademais, que se exija a reflexão como condição de toda e qualquer apreensão prospectiva que se dá -, seria impossível qualquer aproximação teórica cientificamente relevante a esse indivíduo concreto e real sem passar por ela. Não existe a mínima possibilidade seja de se justificar uma investigação sobre qualquer adequação possível entre reflexão e real, seja de se considerar qualquer prospecção, sem que se fundem as bases que possam sustentar a reflexão como ação de "reapresentar" em seu procedimento retrospectivo o que foi "presença" prospectiva. ${ }^{30}$ Diga-se de passagem, uma presença que lança suas raízes no que já foi e se projeta em direção ao que deve ser. É o que procuraremos esclarecer a seguir, a partir do estudo de algumas hipóteses inconsistentes a respeito da natureza do conhecimento filosófico.

\section{Hipóteses Inconsistentes sobre a Natureza do Conhecimento Filosófico}

Distinção sem oposição e integração sem confusão entre reflexão e prospecção. Essa é a fórmula paradoxal a ser equacionada, caso queiramos superar dualismo e monismo no que diz respeito ao conhecimento e a suas pretensões realistas e idealistas. E para tanto é preciso respeitar uma metodologia filosófica rigorosa, sob pena de recair em dificuldades semelhantes àquelas que se queria solucionar.

Seguindo o caminho blondeliano, avancemos, o autor e o leitor, na atividade de estudo do sentido da própria prática filosófica, tendo em vista colher alguns erros de interpretação (parte negativa) e o modo como essa pode ser adequadamente entendida e atuada (parte positiva). Para tanto, em um movimento dialético de inspiração platônico-aristotélica, deveremos assumir cada hipótese que se constrói a esse respeito e analisar suas implicações.

\footnotetext{
${ }^{30}$ Considerando a conclusão da L'Action (Cf. BLONDEL, Maurice. L'Action: essai d'une critique de la vie et d'une science de la pratique. Paris: Quadrige 1993, p. 477-478) e referindo-se à diferença entre ciência da prática e ciência prática, ou o que poderíamos afirmar como sendo o mesmo, reflexão sobre a ação e prospecção, Álvaro Pimentel sustenta essa mesma distinção: “Blondel interpõe a ação no espaço aberto pela distinção entre o conhecimento necessário do ser e o conhecimento possuinte do ser, entre a representação e a presença. Ela é mediadora. Ela sempre realiza essa passagem. Embora nem sempre nos abra ao ser e aos seres, pois há também a ação desfalecente, que, ao contrário, afirma Blondel, nos introduz num estado de privação" (PIMENTEL, Álvaro. A "Lógica da Ação" de Maurice Blondel: explicitação crítica na Ação (1893). Belo Horizonte: UFMG, 2008., p. 45 (Tese de doutorado). [Disponível em: http://www.bibliotecadigital.ufmg.br/dspace/handle/1843/ARBZ-7G5K29. Acesso: 01/11/2016]. E mais adiante: "Blondel fornece-nos alguns traços, sob a forma de convergências e diferenças, entre estas duas espécies de conhecimento, traços que podem ser resumidos na distinção já mencionada entre a representação e a presença" (PIMENTEL, Álvaro. A "Lógica da Ação" de Maurice Blondel: explicitação crítica na Ação (1893). Belo Horizonte: UFMG, 2008., p. 55 (Tese de doutorado). [Disponível em: http://www.bibliotecadigital.ufmg.br/dspace/handle/1843/ ARBZ-7G5K29. Acesso: 01/11/2016].
} 
Nessa direção, Blondel constata em Le point de départ que os procedimentos utilizados pelos filósofos geralmente se organizam de um dos três seguintes modos: 1) ou reflexivamente se procura desenvolver, a partir da noção de percepção ou outras que lhe seguem, uma grande diversidade de metafísicas das ideias, como se a filosofia procedesse exclusivamente da reflexão; 2) ou se afirma o primado da prática para se constituir, sobre o mesmo ponto de vista reflexivo, o sistema dos fins ideais e inteiramente formais da ação, como se a filosofia consistisse exclusivamente em assumir uma atitude crítica; 3 ) ou se procura, refletindo sobre o que se poderia chamar de prospecção (intuição prática), o instrumento inicial, talvez único, e presumidamente a meta da verdadeira filosofia, levada a encontrar seu termo em uma espécie de intuição psicológica. ${ }^{31}$

A seguir, trataremos de investigar cada uma dessas disposições.

\section{a) A reflexão seria a fonte exclusiva da filosofia?}

A defesa da hipótese segundo a qual a reflexão seria a fonte exclusiva da filosofia teria sentido apenas para uma interpretação que entendesse ser a reflexão algo inteiramente isolado em si mesmo, um império próprio e autossuficiente. Muito há por se dizer a respeito das consequências lógicas dessa forma de pensá-la.

Uma das implicações desse isolamento é que a reflexão deverá ser interpretada como heterogênea em relação ao real concreto ${ }^{32} \mathrm{e}$ daí surge uma aporia que colocará em apuros as pretensões ontológicas do realismo: como sendo heterogênea em relação ao real concreto, a reflexão pode ser igualmente adequada para representá-lo? Um problema necessariamente a ser enfrentado para quem se mantém fiel a esse modo de colocar a questão.

Para resolver essa aporia, conservando a reflexão como única fonte da filosofia, dever-se-á ou aderir ao entendimento que faz coincidir metafisi-

${ }^{31}$ Cf. BLONDEL, Maurice. "Le point de départ de la recherche Philosophique" (1906). In: Ouvres Complètes II, 1888-1913. La philosophie de L'Action et la crise moderniste. Paris: PUF, 1997a, p. 536-537.

32 Esta é uma raiz comum tanto ao realismo, quanto ao idealismo crítico. Com efeito, para o realismo, a reflexão encontra-se justificada em seus procedimentos em razão de que se supõe que ela e o real concreto, embora não coincidam, possuem uma ligação ontológica. Consequentemente, seus resultados são interpretados como adequados ao fundo mesmo da realidade. A reflexão funcionaria como um espelho que, em acordo com sua denominação, refletiria o que é. Por sua vez, para o idealismo crítico, abandonada toda a esperança em justificar qualquer relação entre o real concreto e a especulação, pretende-se que a reflexão seja apenas a responsável pela proposição de hipóteses nunca totalmente verificadas ou mesmo inverificáveis sobre esse real, contra o qual investe sem nunca conquistar (Cf. BLONDEL, Maurice. "Le point de départ de la recherche Philosophique" (1906). In:

Ouvres Complètes II, 1888-1913. La philosophie de L'Action et la crise moderniste. Paris: PUF, 1997a, p. 539-540). Adiante veremos em que consiste a inconsistência própria ao idealismo crítico. Por ora, nos ateremos ao realismo para o qual a primeira hipótese inconsistente, que é o objeto atual de estudo, é bem ajustada. 
camente pensar e ser, ou renunciar definitivamente por justificar qualquer adequação entre o pensar subjetivo e uma possível existência objetiva externa ao sujeito, como se faz no idealismo crítico, o qual investigaremos mais adiante. Voltemo-nos, inicialmente, para a primeira alternativa.

A primeira das duas alternativas é assumida pelo realismo e pelo idealismo absoluto, que, em verdade, é um realismo absoluto, tendo em vista que para ele a reflexão não só é uma representação adequada do real concreto, acessível ao pensar, mas coincide com ele, a ponto de se dever afirmar que o idealismo absoluto não se sustenta a não ser pela afirmação radical do realismo.

Esse modo de compreender a reflexão terá repercussões importantes para a ontologia. Interpretar o conhecimento ao modo dos realistas ou idealistas absolutos (realistas absolutos) implicará sacrificar o real ao racional, afirmar como uma mera aparência tudo o que resiste a ser reduzido conceitualmente, toda qualidade irredutível à representação "fagológica". Acredita-se, a partir desse ponto de vista, que essas resistências são apenas o resultado da condição determinada em que se encontra o progresso do espírito ou da cognição, a ser sempre posteriormente completado, superando suas limitações.

Se dissemos anteriormente que o idealismo absoluto não se sustenta sem transformar-se em um realismo absoluto, deveremos dizer agora que, para conservar a reflexão como única fonte da filosofia sem incorrer no perigo de privá-la de suas pretensões ontológicas, o realismo dualista entre ser e pensar, levado a suas extremas consequências, deve reconhecer que somente se justifica por meio de um monismo idealista, ${ }^{33}$ segundo o qual o pensar é adequado ao ser, dando condições para que se construa uma ontologia, apenas porque, de algum modo, deve coincidir com ele.

A raiz comum entre o dualismo realista e o monismo idealista está nessa coincidência, que, não obstante, permanece sempre racionalmente injustificada. O problema ontológico não pode ser resolvido tomando-se os fragmentos ou aspectos artificialmente determinados pela análise reflexiva como correspondendo a tudo do que é, porque um resíduo qualitativo do que é sempre escapa a toda análise. De fato, as diversas ciências nos fazem conhecer apenas migalhas do todo, ou seja, aspectos variados das questões que lhe dizem respeito, sem poderem justificar a reunião dessas mesmas migalhas, dado o estranhamento - não raramente total - entre elas.

\footnotetext{
${ }^{33}$ Para Blondel, o monismo do pensar constitui uma das chaves de leitura mais adequadas para interpretar a filosofia moderna, que de Spinoza, passa pelo idealismo crítico até ser completamente realizado no idealismo absoluto. A esse respeito pode-se recorrer à interpretação que Blondel oferece em L'évolution du spinozisme (BLONDEL, Maurice. "Une des sources de la pensée moderne l'évolution du spinozisme" (1894). In: Oeuvres complètes II: 1888-1913. La philosophie de L'Action et la crise moderniste. Paris: PUF, 1997d, p. 57-88).
} 
Afirmar que essa adequação se realiza é esquecer que a prospecção não é a reflexão, que a prospecção não é a ideia da prospecção, que a reflexão não justifica o sentido das migalhas que colhe a não ser referindo-se a atos postos à luz da prospecção:

[...] todas as percepções, todas as reflexões, todas as investigações, [...] não existem em definitiva senão em função de atos postos à luz da prospecção. Uma filosofia que não dá conta de tal conhecimento e de tais atos faz somente se aproximar de uma sombra projetada e fragmentada, não ao corpo mesmo do ser, em sua solidez e integridade. Ela não saberia alcançar senão a generalidades e idealidades [...]. Tomar cada um dos pedaços artificialmente construídos por análise, e se pôr questões filosóficas a respeito de cada um desses abstratos realizáveis, querer resolver separadamente, a propósito de cada fragmento que não é uma parte, mas um aspecto, o problema ontológico, é, quando se sabe olhar as coisas diretamente e sem rodeios, um non-sens. ${ }^{34}$

Enfim, para que o dualismo realista ou, do mesmo modo, para que o monismo idealista se constitua como uma das bases de sustentação da afirmação da reflexão como única fonte da filosofia é preciso pagar o pedágio do non-sens que aí se evidencia. Mas existe uma alternativa a ele?

Procurando evitar essa inconveniência, uma outra solução ao problema seria abandonar a pretensão de adequação da representação, como se faz no idealismo crítico, continuando a sustentar a reflexão como única fonte da filosofia, mas pagando o preço de reduzir a filosofia a um papel meramente crítico, renunciando ao acesso a qualquer realidade diversa do sujeito, como veremos com mais detalhes a seguir.

\section{b) A atitude crítica seria a fonte exclusiva da filosofia?}

Abandonado o projeto de adequação entre pensar e ser, sem que se perca a tarefa puramente reflexiva da filosofia, a atitude crítica aqui aludida se oferece como uma alternativa possível.

A condição mais elementar disso, porém, é a mudança do que se entende por essa mesma tarefa reflexiva, é o redimensionamento de seu alcance, delimitando-o ao seu uso crítico e subjetivo. Como isso se daria? Por esse caminho, os problemas do monismo/dualismo são realmente superados?

O criticismo pôs em evidência o caráter artificial ou construído do objeto da reflexão, negando que possa existir uma intuição intelectual objetiva. O conhecimento pode ser coerente, mas não consistente, sendo possível garantir a conformidade do conhecimento humano, dado que ele ocorre

${ }^{34}$ BLONDEL, Maurice. "Le point de départ de la recherche Philosophique" (1906). In:

Ouvres Complètes II, 1888-1913. La philosophie de L'Action et la crise moderniste. Paris: PUF, 1997a, p. 538. 
universalmente da mesma forma, mas não sua correspondência ao que é o mundo em si mesmo. A única exigência científica justificável é a da verificação da conformidade do conhecimento que alguém julga ter com a regra estrutural e universal do conhecimento humano, tal e qual este é possível. ${ }^{35}$

Sustentando um projeto gnosiológico que concebe a filosofia como uma crítica da razão, o idealismo crítico tem por meta principal fazer a razão respeitar os limites da experiência possível, descobrindo as consequências desse respeito ou de sua violação ${ }^{36}$.

É bem verdade que um de seus resultados mais expressivos foi o reconhecimento da ilegitimidade das pretensões ontológicas ou metafísicas da razão pura teórica no que concerne ao conhecimento da coisa em $\mathrm{si}^{37}$ Contudo, o criticismo continua conferindo um valor ontológico a uma parte privilegiada do conhecimento, "porque se fundou sobre a ação refletente do juízo como sobre uma intuição moral"38. A ontologia não é por ele completamente condenada ao non-sens, porque, mesmo com sua revolução copernicana do conhecimento, certa parcela da realidade continuaria ainda a ser acessível quando do uso prático da razão, aplicada a reflexivamente descobrir, tal e qual é, o reino da moralidade. ${ }^{39}$

\footnotetext{
${ }^{35} \mathrm{Na}$ Crítica da Razão Pura lê-se: "Até hoje admitia-se que o nosso conhecimento se devia regular pelos objetos; porém, todas as tentativas para descobrir a priori, mediante conceitos, algo que ampliasse o nosso conhecimento, malogravam-se com este pressuposto. Tentemos, pois, uma vez, experimentar se não se resolverão melhor as tarefas da metafísica, admitindo que os objetos se deveriam regular pelo nosso conhecimento [...]. Se a intuição tivesse que se guiar pela natureza dos objectos, não vejo como deles se poderia conhecer algo a priori [que sirva de critério de juízo para se estabelecer o conhecimento válido]; se, pelo contrário, o objeto (enquanto objecto dos sentidos) se guiar pela natureza da nossa faculdade de intuição posso perfeitamente representar essa possibilidade" (KANT, Immanuel. Crítica da Razão Pura. $5^{\text {a }}$ ed., Lisboa: Fundação Calouste Gulbekian, 2001b, B XVI-XVII, p. 19-20). ${ }^{36}$ Algumas passagens da Crítica da Razão Pura são consideravelmente claras a este respeito: “[...] desta dedução da nossa capacidade de conhecimento a priori, na primeira parte da Metafísica, extrai-se um resultado insólito e aparentemente muito desfavorável à sua finalidade, da qual trata a segunda parte; ou seja, que deste modo não podemos nunca ultrapassar os limites da experiência possível, o que é precisamente a questão mais essencial desta ciência" (KANT, Immanuel. Crítica da Razão Pura. $5^{\mathrm{a}}$ ed., Lisboa: Fundação Calouste Gulbekian, 2001b, B XVI-XVII, B XIX, p. 21).

37 " [...] a verdade do resultado que obtemos nesta primeira apreciação do nosso conhecimento racional a priori é-nos dada pela contra-prova da experimentação, pelo facto desse conhecimento apenas se referir a fenômenos e não às coisas em si que, embora em si mesmas reais, se mantêm para nós incognoscíveis" (KANT, Immanuel. Crítica da Razão Pura. $5^{\mathrm{a}}$ ed., Lisboa: Fundação Calouste Gulbekian, 2001b, B XX, p. 21-22)

${ }^{38}$ BLONDEL, Maurice. "Le point de départ de la recherche Philosophique" (1906). In: Ouvres Complètes II, 1888-1913. La philosophie de L'Action et la crise moderniste. Paris: PUF, 1997a, p. 540.

${ }^{39}$ A respeito dos objetivos da Crítica da Razão Prática, afirma Kant: "Aqui se explica, antes de mais nada, o enigma da crítica: como na especulação se possa negar a realidade objetiva ao uso suprassensível das categorias [assim, que a razão pura deve ser aplicada somente nos limites da experiência possível], e todavia que esta realidade se possa conceder relativamente aos objetos da razão pura prática [assim, que a razão pura prática possa se lançar em uma investigação suprassensível]" (KANT, Immanuel. Critica della Ragione Pratica. $3^{\text {a }}$ ed., Roma/ Bari: Laterza, 2001a., § 8, p. 7).
} 
A meta do criticismo parece ser dupla: desiludir a razão em seu uso especulativo em relação às suas pretensões de conhecer adequadamente o fundo mesmo das coisas externas ao sujeito e mostrar o alcance numênico da razão em seu uso prático. E tudo isso sem emigrar do domínio da razão pura, ou seja, de seu uso puramente reflexivo. Para o criticismo, a reflexão continua a ser a única fonte de acesso ontológico ao mundo numênico. Se a representação não é um conhecimento numênico, ou seja, do que é em si mesmo, a ação refletente do juízo, por onde se esclarece o imperativo categórico, funciona como uma intuição moral. Em outros termos, a razão pode descobrir leis ou critérios de juízo, que são de ordem numênica. E por quê? Porque essas leis são puramente subjetivas.

Diferentemente do que propõe o dualismo realista, para o criticismo o númeno (a realidade em si) não se atinge pela aplicação da razão sobre os objetos considerados como coisas em si externas, mas sobre o próprio sujeito e seus fenômenos internos, procurando-lhes as condições. ${ }^{40}$ Nesse sentido, porque a intuição moral é o conhecimento que a razão tem de si mesma, o númeno está ao alcance da reflexão. A intuição moral é a expressão do sujeito enquanto sujeito; a razão prática é a razão aplicada ao sujeito, isolado por uma reflexão que separa na ação moral "o fato da moralidade" ${ }^{\prime 1}$ para lhe submeter a seus procedimentos exclusivos. A moralidade é como que transposta abstratamente e isolada em uma ideia da moralidade - que não é propriamente uma imagem, mas uma regra lógica sobre o juízo moral - para melhor se lhe apreender os atributos específicos, purificando-a da materialidade dos atos. Uma purificação necessária, caso se queira justificar a possibilidade de um conhecimento além do conhecimento fenomenal, sempre relativo às condições de possibilidade do conhecimento próprias do sujeito, ainda que de um sujeito transcendental.

\footnotetext{
${ }^{40}$ A respeito de sua Crítica da Razão Prática, afirma Kant: "[Aqui] se apresenta uma confirmação, que se poderia apenas esperar e que é por demais satisfatória, da coerência do modo de pensar da Crítica especulativa, no que concerne a que enquanto esta não deixava de considerar somente como fenômenos os objetos da experiência como tais, mas também nosso sujeito, e não menos a lhes pôr como fundamento as coisas em si mesmas, e então de não ter todo o suprassensível por invenção e o seu conceito vazio de conteúdo; agora a razão prática, por si mesma e sem ter feito um acordo com a razão especulativa, procura a realidade a um objeto suprassensível da categoria da causalidade, isto é, à liberdade (ainda que como conceito prático, e somente por uso prático), e por isso confirma mediante um fato aquilo que com a especulação poderia ser apenas pensado. Ao mesmo tempo, junto com essa, a estranha, ainda que indubitável, asserção da Crítica especulativa, de que também o sujeito pensante é para si mesmo, na intuição interna, simplesmente um fenômeno, recebe a sua plena confirmação na Crítica da razão prática, e em modo tal que se deveria chegar a esta confirmação também se a primeira Crítica não tivesse demonstrado de fato essa proposição" (KANT, Immanuel. Critica della Ragione Pratica. $3^{a}$ ed., Roma/Bari: Laterza, 2001a.§ 9-10, p. 9). ${ }^{41} \mathrm{O}$ "fato" para Blondel é uma representação de uma síntese real e ativa. O "fato da moralidade" é a representação especulativa, vinculada à razão prática, da ação moral.
} 
Por seu caráter misto, sendo apenas em parte subjetivo, o conhecimento fenomenal é presa de uma instabilidade insuperável. Evidentemente, como qualquer outro conhecimento, ele não seria nada se não fosse relativo a um sujeito, a um centro de sentido. Todavia, porque misto, ou seja, concernente ao sujeito e dependente também de uma materialidade a ele alheia e diretamente inacessível, esse conhecimento deve renunciar à pretensão de possibilitar o acesso às coisas mesmas e contentar-se por sustentar hipóteses nunca totalmente verificadas.

Isso significaria que a razão em sua aplicação teórica deve contentar-se apenas com o conhecimento fenomênico? A resposta é não. A instabilidade do conhecimento fenomênico não se explica por ele ser relativo ao sujeito, mas por ele não ser puramente subjetivo. O conhecimento numênico sim é estável. Não podemos aceder ao numênico através do conhecimento que temos das coisas externas, mas, como ocorre com a intuição moral, podemos ter acesso a um conhecimento numênico através da consideração de nossa própria subjetividade, de suas estruturas, que embora sejam $a$ priori só podem ser descobertas a posteriori por análise da experiência, cognitiva ou moral.

Por procedimentos análogos aos utilizados para se atingir a intuição moral, a crítica kantiana em sua analítica transcendental, presente na Crítica da Razão Pura, também consegue isolar o que de puramente subjetivo e universal há no conhecimento fenomênico. Os procedimentos da lógica transcendental possibilitam a descrição da estrutura universal do conhecimento, unificada pela apercepção transcendental: sensação, entendimento e razão. Mas essa descrição é, na verdade, o resultado da reflexão aplicada a si mesma, do eu penso que, pensando a si mesmo - embora afirme a transcendência de sua síntese última, já que não se pode conhecer a apercepção transcendental -, alcança um conhecimento necessário a respeito do uso da razão pura teórica, que se soma ao outro tipo de conhecimento necessário vinculado à razão pura prática - ou seja, o fato da moralidade -, como modalidades de conhecimento numênico.

Em outras palavras, malgrado ou bom grado, supõe-se também como possível, além da intuição moral, uma intuição ou um conhecimento imediato (numênico) do sujeito no que concerne à estrutura de seu conhecimento - as formas da sensibilidade, as categorias do entendimento e as ideias da razão - e às leis de funcionamento da razão pura em seu uso teórico. Ainda que a descrição da estrutura e das leis possa ser acidental, há algo aí que permanece essencial à filosofia kantiana: a necessidade de uma estrutura, como elemento ou condição de possibilidade de necessárias leis de funcionamento da razão pura em seu uso teórico, seja lá como elas se deem realmente.

Em suma, por um lado a razão pura no que concerne a sua aplicação prática é intuída como imperativo moral totalmente abstrato, como lei moral, e 
por outro a razão pura no que concerne a seu uso teórico é intuída como uma lei segundo a qual todo conhecimento fenomenal é possível.

Assim procedendo, entretanto, o criticismo cria um problema análogo ao anterior: a pesquisa filosófica surgiria e se sustentaria de modo legítimo somente dentro dos limites "exclusivos" da razão pura e, em última análise, da apercepção transcendental. Mas o que não pode ser fornecido pela reflexão do objeto - ou seja, o ponto de partida da filosofia -, o poderia ser pela reflexão sobre o sujeito, lá onde ele aparece na pureza de sua autonomia, como lei moral e lei crítica - científica - para si mesmo?

Pressupondo que sim, a metafísica dos costumes e a crítica da razão pura conferem à reflexão sobre a moralidade e à reflexão sobre as leis da razão pura em seu uso teórico um poder análogo ao que havia sido conferido por algumas metafísicas mais antigas à reflexão objetiva. Essas pensavam falar ontologicamente quando especulavam, substituindo os seres concretos pela ideia dos seres. Também a metafísica dos costumes e a crítica da razão pura, como que olhando para o que elas mesmas haviam criticado, paradoxalmente veem nos procedimentos da reflexão (nos hábitos reflexivos) a única forma possível de ainda se pensar uma ontologia. Como nos diz Blondel:

Aqui ainda a filosofia é faltosa de um ponto de partida distinto e original: ela começa a partir das formas derivadas da reflexão e da ação. Permanece sob a influência dos resultados do esforço anterior do qual ela própria provém, em vez de se ligar a esse seu esforço inicial. ${ }^{42}$

Resultados da abstração, não só as leis do emprego da razão em seu uso teórico são formas derivadas ou representações que não dão acesso ao sujeito real, como a ideia da moralidade também não o faz, não sendo a própria moralidade ou a vida enquanto prática efetiva. Nos dois casos, restringe-se a filosofia aos limites da razão pura. Mas fazer isso é o mesmo que isolá-la na reflexão, incorrendo nos mesmos problemas já anteriormente estudados, impossibilitando a superação do dualismo (ou do monismo) entre conhecimento e realidade, que é o original motivo de inspiração do criticismo ou o anseio fundamental de seu esforço inicial. Como antes, o mesmo juízo pode ser aqui aplicado: impossível confundir reflexão e prospecção.

Conquistada a certeza de que a filosofia não pode se limitar exclusivamente à reflexão, resta-nos ainda verificar se ela não poderia partir de uma intuição psicológica (prospecção), isoladamente considerada, e a ela conduzir.

${ }^{42}$ BLONDEL, Maurice. "Le point de départ de la recherche Philosophique" (1906). In:

Ouvres Complètes II, 1888-1913. La philosophie de L'Action et la crise moderniste. Paris: PUF, 1997a, p. 541. 


\section{c) A filosofia partiria da intuição psicológica?}

Segundo essa hipótese, o ponto de partida da filosofia seria uma intuição ou imediação afetiva: "imediação de um sentido íntimo" ${ }^{43}$. Usando a análise contra a análise, a reflexão contra a reflexão, o pensar geraria essa imediação por meio de um olhar espontâneo sobre as coisas e sobre ele mesmo. Essa espontaneidade seria marcada pelo esforço por apreender a vida do espírito em seu estado primitivo, no contato fecundo entre coisas e consciência. Segundo essa posição, sem conduzir a reflexão na direção dessa espontaneidade, o pensar não pode colocar-se senão fora da "consciência da realidade mesma" ${ }^{44}$.

Para servir à consciência da realidade, assim, o pensar deve entregar-se à sua intuição prática mais primitiva. Depois de fazer da reflexão o instrumento de perversão da filosofia - e da ontologia - , se a resgata como instrumento de sua salvação como que indicando que a filosofia é apenas um retorno consciente e reflexivo aos dados da intuição prática. Mas, em verdade, a que essa manobra leva? Seu resultado é mesmo o prometido?

Nesse movimento o que ocorre de fato é uma transformação da prospecção em reflexão. Mas por quê? Simplesmente, porque o retorno consciente e reflexivo aos dados da intuição tem como resultado apenas uma representação da imediação afetiva, da prospecção, mas não ela mesma. E, dessa forma, também essa última hipótese não soluciona o problema a que se propõe.

Somente uma opção, entre as duas seguintes, é viável, no que diz respeito a uma possível relação entre pensar e ação:

a) ou permanecemos fieis à tese segundo a qual o pensar reflexivo é apenas um artificio a serviço das parcialidades da ação e, assim, ao entendimento de que o retorno à plenitude da intuição significará para o conhecimento uma total anulação de si, um suicídio subjetivo, que assume as vestes de uma consciência total ou completamente objetiva, de algum modo equivalente a uma consciência neutra ou a uma percepção impessoal, como se fosse possível a alguém conhecer desfazendo-se de si mesmo, sob o influxo da crença implícita de que "perceber todas as influências de todos os pontos de todos os corpos possíveis seria descer ao estado de objeto material" ${ }^{45}$. Não é difícil entender que isso significa pretender, como se

\footnotetext{
${ }^{43}$ BLONDEL, Maurice. "Le point de départ de la recherche Philosophique" (1906). In: Ouvres Complètes II, 1888-1913. La philosophie de L'Action et la crise moderniste. Paris: PUF, 1997a, p. 541.

${ }^{44}$ BLONDEL, Maurice. "Le point de départ de la recherche Philosophique" (1906). In: Ouvres Complètes II, 1888-1913. La philosophie de L'Action et la crise moderniste. Paris: PUF, 1997a, p. 541.

${ }^{45}$ BLONDEL, Maurice. "Le point de départ de la recherche Philosophique" (1906). In: Ouvres Complètes II, 1888-1913. La philosophie de L'Action et la crise moderniste. Paris: PUF, 1997a, p. 544.
} 
fosse realmente possível, utilizar o conhecimento contra ele mesmo, como se usa de uma escada para subir em algum lugar mais elevado, podendo-se, depois, permanecer aí, livrando-se dela. Mas, dado que isso fosse realmente possível, depois de livrar-se da reflexão e, consequentemente, de sua própria consciência subjetiva, o que restaria ao homem?

b) Ou "se procurará na ação um meio de verificar e enriquecer o conhecimento, como no conhecimento um meio de esclarecer e preparar, de inventariar e de promover a ação" ${ }^{\prime 4}$.

Nessa última direção, não basta "dizer" que o conhecimento é um instrumento da ação para que a "realidade concreta" do conhecimento verdadeiro seja acessada: "conhecer que o verdadeiro conhecimento conduz ao concreto, não dá a realidade concreta do conhecimento verdadeiro" ${ }^{\prime 4}$. Para tanto, é necessário o engajamento ativo. É preciso completar a teoria do pensar-agente (reflexão) pela prática da ação-pensante (prospecção).

E, dessa forma, chegamos ao fim do estudo das primeiras três hipóteses a respeito da origem da filosofia. O que concluir dele?

\section{d) A colaboração entre prospecção e reflexão}

O estudo das três últimas hipóteses nos leva a uma certeza: sem o engajamento ativo, sem incluir a prospecção, seja lá como se defina o papel da reflexão, não há como escapar de prejuízos ontológicos; não há como tomar "o que é" "pelo que é" e não "por sua representação". Em oposição ao prejuízo especulativo que faz a meta da vida coincidir com o teorizar, a função da reflexão deve ser determinada em relação à ação e não a uma ideia da ação, nem muito menos a uma ideia de um conhecimento abstrato:

Uma filosofia que, enganada pelo nobre instinto de especulação, concluiria que theoréin é o fim da vida, que o objeto dessa vida do espírito é uma realidade imediatamente dada e um "fim em si", pareceria a uma moral que, enganada pelos atrativos os mais evidentes da natureza, não procuraria realidades ulteriores que, por estarem escondidas aos sentidos, não seriam menos, no que concerne à razão, a causa e a regra verdadeira de seus atrativos mesmos. ${ }^{48}$

É preciso, porém, evitar o excesso contrário. Embora a reflexão não possa substituir a ação, não possa substituir a vivência e a imediação relacional

\footnotetext{
${ }^{46}$ BLONDEL, Maurice. "Le point de départ de la recherche Philosophique" (1906). In: Ouvres Complètes II, 1888-1913. La philosophie de L'Action et la crise moderniste. Paris: PUF, 1997a, p. 544.

${ }^{47}$ BLONDEL, Maurice. "Le point de départ de la recherche Philosophique" (1906). In:

Ouvres Complètes II, 1888-1913. La philosophie de L'Action et la crise moderniste. Paris: PUF, 1997a, p. 544.

${ }^{48}$ BLONDEL, Maurice. "Le point de départ de la recherche Philosophique" (1906). In:

Ouvres Complètes II, 1888-1913. La philosophie de L'Action et la crise moderniste. Paris: PUF, 1997a, p. 544.
} 
da prospecção, que nos abre à experiência mais primitiva do "que é", ela não pode ser dela isolada. Com efeito, como já precisamos, não há teoria ou ideia sem uma prospecção e não há prospecção que se sustente sem reflexão:

No ponto de partida de toda ciência, de toda arte, de toda indústria se encontra um desejo a ser satisfeito, um desejo sem o qual a reflexão não seria produzida e não teria nada produzido. Mas, ao mesmo tempo, a ação não se produziria ela própria, ela não produziria seus efeitos úteis senão ao preço de uma reflexão que lhe fornecesse seus meios e que, à medida que ela lhe permite atingir seus fins sucessivos, a ajuda a discernir, a perseguir seu termo superior. ${ }^{49}$

Como em uma caminhada, o pensamento precisa igualmente se fundar sobre o passo já dado como sobre o passo que está por vir. Em outras palavras, o pensamento nasce da ação, sustenta-se ativamente e se orienta para ela. A origem e a meta da especulação é a prática, a própria especulação é uma prática e o fim da prática é elucidado pela especulação, de modo que isolar reflexão e prospecção é um non-sens.

Especulação e prospecção se remetem permanentemente uma à outra. É por essa relação que o que é existe para mim. Com efeito, por um lado, nada existe para mim que não tenha relação com minha ação e prospecção. Por outro, nem tampouco eu existiria para mim mesmo sem a capacidade de abstrair reflexivamente, do contínuo primitivo da consciência e da sensação, objetos que, para sustentar minha análise, afirmo como sendo "mesmo quando eu só sei rudimentarmente o que eles são e o que é o ser" ${ }^{\prime \prime 5}$. Enfim, por ser um artifício, a reflexão não é por isso contra naturam ou mesmo dispensável:

O que é artificial e frustrante não é, então, empregá-la, segundo os desejos da natureza, ao serviço do trabalho solidário do pensar e da ação, mas pretender ou usar exclusivamente ou prescindir totalmente dos resultados dessas análises, para constituir especulativamente uma filosofia do conhecimento e da existência. ${ }^{51}$

Dito isso, poderíamos concluir que a filosofia seria o esforço por relacionar prospecção e reflexão?

Se a pergunta for feita simplesmente sob esses termos a resposta deverá ser "não". De fato, colocada dessa forma, a questão parece pressupor que

\footnotetext{
${ }^{49}$ BLONDEL, Maurice. "Le point de départ de la recherche Philosophique" (1906). In: Ouvres Complètes II, 1888-1913. La philosophie de L'Action et la crise moderniste. Paris: PUF, 1997a, p. 545.

${ }^{50}$ BLONDEL, Maurice. “Le point de départ de la recherche Philosophique" (1906). In: Ouvres Complètes II, 1888-1913. La philosophie de L'Action et la crise moderniste. Paris: PUF, 1997a, p. 545.

${ }^{51}$ BLONDEL, Maurice. “Le point de départ de la recherche Philosophique" (1906). In: Ouvres Complètes II, 1888-1913. La philosophie de L'Action et la crise moderniste. Paris: PUF, 1997a, p. 546.
} 
reflexão e prospecção seriam distintas e isoladas e daí a necessidade de um esforço por relacioná-las. Isso levaria mais uma vez a uma recaída dualista. Mas, então, como poderíamos repensar a questão?

O ponto de partida da filosofia se encontra na inquietude epistêmica que a leva a assumir a tarefa de procurar não propriamente relacionar como duas séries isoladas, mas integrar cada vez mais reflexão e prospecção, ou melhor, reintegrar para o pensamento o que espontaneamente já se encontra integrado. Sua tarefa é de aprimorar o conhecimento em ato, que se constitui na dinâmica relação entre a prospecção, onde a reflexão encontra suas condições, e a reflexão, cujo fim consiste em esclarecer e enriquecer a prospecção. Reflexão e prospecção são noções que designam elementos da síntese que é o conhecimento em ato e, portanto, não podem ser isoladas uma da outra.

Finalmente, do que discutimos até o momento, podemos afirmar com segurança algumas conclusões:

1) A filosofia não pode proceder a partir da reflexão isolada, porque daí não se pode tocar nenhum ponto de partida concreto ou real, mas apenas representações abstratas.

2) A filosofia não pode proceder a partir da prospecção isolada, porque é impossível isolá-la, a não ser transformando-a em uma espécie de reflexão bastarda (ideia da prospecção), que em fins de conta deveria conduzir não só ao agnosticismo, mas rigorosamente à inconsciência, de modo que o ponto de chegada (a inconsciência) destruiria o ponto de partida da pesquisa (a pretendida prospeç̧ão).

3) A filosofia, ademais, não pode se propor como meta de seu esforço inicial a criação de uma relação, anteriormente não existente, entre prospecção e reflexão, ação inteligente e inteligência agente, porque isso pressuporia sempre um modo de interpretar a ação como sendo equivalente à ideia da ação e de especular sobre entidades e generalidades isoladas.

4) Por fim, todas as doutrinas revistas até aqui parecem compartilhar o vício comum de subordinar a pesquisa filosófica ao "conhecimento pelo conhecimento e para o conhecimento" ${ }^{52}$. Mesmo aquelas que têm como pretensão subordinar a teoria à prática, como diz o próprio Blondel "se apresentam ainda sob os traços de uma teoria da qual é preciso dizer que é 'um fim em si' e um 'meio para si mesma'"153.

\footnotetext{
${ }^{52}$ BLONDEL, Maurice. "Le point de départ de la recherche Philosophique" (1906). In:

Ouvres Complètes II, 1888-1913. La philosophie de L'Action et la crise moderniste. Paris: PUF, 1997 a, p. 546.

${ }^{53}$ BLONDEL, Maurice. "Le point de départ de la recherche Philosophique" (1906). In:

Ouvres Complètes II, 1888-1913. La philosophie de L'Action et la crise moderniste. Paris: PUF, 1997 a, p. 546-547.
} 
Tendo já sido esclarecido quais pontos de partida não podem amparar uma filosofia que, ao mesmo tempo, supere o dualismo e o monismo entre pensar e ser, não se sujeitando a antinomias intransponíveis, como é o caso da que se estabelece entre realismo e idealismo, chega agora o momento de estudar qual ponto de partida será necessário para que se a sustente.

\section{O Ponto de Partida da Investigação Filosófica: a Elucidação da Prospecção pela Reflexão}

O problema inicialmente proposto no primeiro artigo que compunha Le point de départ relaciona-se com o esclarecimento da duplicidade de como a filosofia se apresenta, constituindo, de certo ponto de vista, uma obra de ciência e, de outro, uma obra de vida. A discussão foi conduzida de modo a mostrar como a filosofia não poderia ser isoladamente uma obra de ciência (isolando-se na reflexão) ou uma obra de vida (isolando-se na prospecção) sem cair em insuperáveis paradoxos.

Resta, entretanto, outra estrada a ser percorrida. É preciso forçar ainda mais a pesquisa, estudando uma alternativa, que poderia ser expressa pela pergunta: a filosofia poderia ser um conhecimento popular, universal e engajado na ação comum da humanidade (obra de vida) e, ao mesmo tempo, técnico e especializado (obra de ciência)?

A esse respeito, podemos colher em Le point de départ a proposta de Blondel:

[...] nem as abstrações da análise especulativa saberiam, tomadas como tais, fornecer à filosofia a realidade real, aquela que é não um simples objeto de pensar ou uma soma artificial de símbolos, mas a plenitude mesma dos seres concretos; nem as intuições da síntese prática saberiam, por elas mesmas, nos colocar em possessão da verdadeira verdade, aquela que não é um sentimento confuso ou uma definição nominal, mas a visão distinta, expressiva, utilizável do que é. Trata-se agora, então, de levar em consideração igualmente estes dois aspectos inseparáveis e irredutíveis do conhecimento, de maneira a lhes tornar solidários e complementares na filosofia, como eles são em todo homem que pensa agindo e que age pensando. ${ }^{54}$

"Pensar agindo e agir pensando", "prospecção e reflexão", dois aspectos do conhecimento, irredutíveis, mas inseparáveis. O conhecimento em ato procede sempre por reflexão e prospecção. Ora, por suas pretensões radicais e universais, a filosofia não pode se abster do estudo da natureza mais original do conhecimento. Quando assume a tarefa de esclarecer, de levar luz a essa integração real entre prospecção e reflexão, fazendo com

${ }^{54}$ BLONDEL, Maurice. “Le point de départ de la recherche Philosophique" (1906). In: Ouvres Complètes II, 1888-1913. La philosophie de L'Action et la crise moderniste. Paris: PUF, 1997a, p. 548. 
que ela seja cada vez mais para o conhecimento o que já é concretamente, a filosofia se torna realmente livre das amarras da dialética abstrata que a prendia em antinomias insuperáveis.

Sem renunciar a seu status científico próprio e somente porque não o faz, a filosofia pode ser também uma obra de vida. Somente por não se entregar aos erros de uma compreensão inconsistente, que insiste em confundir o que é com a ideia do que é, a filosofia pode guardar seu interesse e seu alcance universal e comungar com a vida geral que ela se empenha em esclarecer e promover.

De uma parte, vista como uma disciplina técnica e como uma pesquisa reflexiva, do ponto de vista especulativo, a filosofia começa quando expressamente subordina toda a sua investigação ao problema que levanta em nós a relação entre consciência e ação ou, ainda, reflexão e prospecção: "A reflexão não se torna estritamente filosófica senão quando se propõe inicialmente como tarefa elucidar a síntese integral da prospecção"

No entanto, para se conservar estritamente filosófico, ainda desse ponto de vista especulativo, o conhecimento deve respeitar certos limites: a reflexão deve se interditar toda pretensão prematuramente ontológica na elucidação da prospecção. No decurso de sua pesquisa, não deve tomar nenhuma de suas representações e problemas como entidades isoladas, mas os considerar conjuntamente e sob a luz do uno e do todo que se oferece no conhecimento em ato - "summatim et sub specie unius et totius" 56 . Essa é a condição metódico-formal da reflexão filosófica: não conhecer nada senão à luz do todo sintético da ação, dada em sua imediação mais primitiva como prospecção.

De outra parte, como obra de liberdade e direção prática, do ponto de vista da prospecção, a filosofia começa somente quando a prospecção se empenha em reintegrar em si todas as conquistas fragmentadas da reflexão. Em outras palavras, quando a prospecção não se limita à intuição global que é suficiente para a ação espontânea ou aos desígnios particulares da vontade, que escondem sua inclinação mais fundamental, mas se empenha em atingir e assimilar as realidades concretas que se lhe oferecem, a partir da vida, prevendo e preparando seu desfecho. ${ }^{57}$

\footnotetext{
${ }^{55}$ BLONDEL, Maurice. "Le point de départ de la recherche Philosophique" (1906). In: Ouvres Complètes II, 1888-1913. La philosophie de L'Action et la crise moderniste. Paris: PUF, 1997 a, p. 549.

${ }^{56}$ BLONDEL, Maurice. "Le point de départ de la recherche Philosophique" (1906). In:

Ouvres Complètes II, 1888-1913. La philosophie de L'Action et la crise moderniste. Paris: PUF, 1997a, p. 548-549.

${ }^{57}$ Cf. BLONDEL, Maurice. "Le point de départ de la recherche Philosophique" (1906). In: Ouvres Complètes II, 1888-1913. La philosophie de L'Action et la crise moderniste. Paris: PUF, 1997a, p. 549.
} 
Para isso, entretanto, é preciso respeitar algumas condições: "interditar-se toda satisfação sentimental, toda conclusão prematuramente moral ou religiosa" ${ }^{15}$, tendo em vista "não considerar nada, por mais sintético que seja, senão metodicamente e progressivamente, singillatim et per gradus debitos" 59 . A prospecção não deve aceitar nenhuma conclusão sem que essa assim se o mostre para a razão, a partir do exame minucioso e progressivo de suas particularidades. Essa é a condição metódico-formal da prospecção filosófica: não concluir nada senão à luz da reflexão analítica.

As condições metódico-formais da reflexão e da prospecção asseguram que essas se exijam reciprocamente, como de fato se exigem realmente, por uma sorte de circunsessão $0^{60}$, que é o conhecimento em ato. Nele, a reflexão e a prospecção estritamente filosóficas se exigem mutuamente. No conhecimento em ato, a prospecção se faz sob a luz da reflexão e essa conhece sob o amparo da prospeç̧ão. ${ }^{61}$ Fiel a essas condições, a filosofia encontra seu equilíbrio:

Porque assim compreendida a filosofia não aparece mais como um simples estrato da vida, como uma representação, como um espetáculo. Ela é a vida mesma tomando consciência e direção de si, atribuindo ao pensar todo o seu papel e nada além de seu papel legítimo, tendendo à equação entre conhecimento e existência, e desenvolvendo simultaneamente a realidade de nosso ser entre os seres e a verdade dos seres em nós [.... ${ }^{62}$

Em suma, a consideração do aspecto especulativo (reflexivo) do conhecimento em ato conduz à verdade do seu aspecto prático (prospectivo), ao seu sentido real, concreto. A consideração do aspecto prático (prospectivo) do conhecimento em ato nos faz ver e exige a realidade do seu aspecto especulativo (reflexivo). Verdade prática e realidade ideal se encontram no conhecimento em ato.

\footnotetext{
${ }^{58}$ BLONDEL, Maurice. "Le point de départ de la recherche Philosophique" (1906). In: Ouvres Complètes II, 1888-1913. La philosophie de L'Action et la crise moderniste. Paris: PUF, 1997a, p. 549.

${ }^{59}$ BLONDEL, Maurice. “Le point de départ de la recherche Philosophique” (1906). In:

Ouvres Complètes II, 1888-1913. La philosophie de L'Action et la crise moderniste. Paris: PUF, 1997a, p. 549.

${ }^{60}$ Do latim circumsessione. Um termo técnico da teologia cristã que designa a união íntima entre as três pessoas divinas no mistério da Santíssima Trindade. Na filosofia blondeliana, designa a união íntima das partes de uma síntese. Sobre a circunsessão é preciso dizer que o esquema interpretativo aplicado é o de, à luz da stérēsis, pensar o conhecimento em ato, o conhecimento real, a verdade real, como uma síntese entre prospecção e reflexão. Assim, duas células fundamentais do blondelianismo são aqui tocadas: o vínculo (síntese) e a stérēsis. ${ }^{61}$ Cf. BLONDEL, Maurice. "Le point de départ de la recherche Philosophique" (1906). In: . Ouvres Complètes II, 1888-1913. La philosophie de L'Action et la crise moderniste.

Paris: PUF, 1997a, p. 549.

${ }^{62}$ BLONDEL, Maurice. "Le point de départ de la recherche Philosophique" (1906). In: Ouvres Complètes II, 1888-1913. La philosophie de L'Action et la crise moderniste. Paris: PUF, 1997a, p. 549-550.
} 


\section{Considerações finais: as condições metódico-formais da filosofia}

Porque reflexão e prospecção são inseparáveis, enquanto partes da síntese que é o conhecimento em ato, apenas aparentemente as condições metódico-formais da filosofia apresentam certa duplicidade. Em verdade, essas condições se identificam. Sua distinção se deve somente ao modo em que são aproximadas, ora sob o ponto de vista da reflexão, ora sob a perspectiva da prospecção. Trata-se, assim, da mesma reserva suspensiva. Ela se identifica como sendo uma tarefa, podendo ser enunciada na forma do que Blondel chamará em Le point de départ da proposição fundamental da filosofia. Podemos apresentá-la com a seguinte formulação: no conhecimento em ato é preciso evitar, desde seu ponto de partida mais remoto, toda conclusão prematuramente ontológica, moderando a prospecção pela reflexão e essa por aquela, de forma a reintegrá-las cada vez mais no pensar como e porque já o são na vida.

Com essa enunciação, através de um só golpe, Blondel parece pretender resgatar o aspecto crítico da filosofia (reserva suspensiva) e anunciar sua tarefa. A crítica filosófica blondeliana, dessa forma, procura não enclausurar a filosofia nos limites da própria crítica. Sua função não é puramente crítico-negativa. Diversamente, esse emprego da crítica filosófica permite descobrir no seu momento suspensivo, na necessidade de moderar a prospecção pela reflexão e vice-versa, o seu momento construtivo: a sua tarefa de contribuir por reintegrar prospecção e reflexão, por meio da elucidação da prospeç̧ão pela reflexão, tendo em vista o progresso da vida, ou melhor, a consumação da ação.

Esse esforço de elucidação da prospeç̧ão pela reflexão procurando sempre mais a sua mútua integração é, segundo a filosofia blondeliana, a marca distintiva ou específica da cientificidade própria do conhecimento filosófico, que, não obstante, conserva os traços do caráter universalista por ele tradicionalmente assumido. Um universalismo crítico com uma fisionomia própria, segundo o qual é preciso:

a) não partir de nenhum ponto determinado, porque isoladamente nada é totalmente determinável;

b) não considerar isoladamente nenhum sujeito ou objeto, porque não se os pode tratar como átomos de conhecimento ou subsistência sem menosprezar suas relações de interdependência;

c) não se fixar em nenhuma solução parcial e provisória, porque pretendendo, para justificar o conhecimento, "analisar as coisas como empirista, as ideias como idealista, os seres como realista, os fatos como positivistas, 
os estados de consciência como fenomenistas, apenas se toma conclusões artificiais ou hipótese por pontos de partida verdadeiros" ${ }^{\prime 63}$.

Em síntese, da parte do filósofo seria preciso compreender que esse tem sempre que subordinar sua análise a uma reserva suspensiva e a uma questão universal, que não permite nenhuma conclusão definitiva antes de conduzir sua atenção pela perspectiva do todo. É preciso "partir do que parece total e mesmo final, e procurar, não em um objeto materialmente definido, mas no modo de enxergar a integralidade dos problemas, o objeto formal e a característica precisa da filosofia" ${ }^{\prime 64}$.

Segundo essas coordenadas, no ponto de partida da pesquisa filosófica se encontra, então, uma atitude, ${ }^{65}$ condição do filosofar, que consiste em orientar o conhecimento a partir do ponto de vista do todo; embora se reconheça a dificuldade em defini-la e, mais ainda, em praticá-la metodicamente em todo detalhe da investigação filosófica.

De fato, em filosofia não é difícil constatar que nas mais diversas doutrinas se reconheça seu caráter universalista; que se consinta no esforço em respeitá-lo; que não se desconheça que o que parece difícil de respeitar sob o ponto de vista especulativo é natural sob o ponto de vista da vida (prática), que "em seu equilíbrio perpetuamente instável e em seu movimento, tende a se adaptar sem cessar a seu ambiente total"66. Geralmente, até se reconhece que, procedendo por reflexões fragmentárias e se apegando a resultados parciais, a maioria das doutrinas filosóficas usa de um artifício.

Entretanto, não é tão simples definir em que consista precisamente essa inclinação universalista e, mais ainda, que procedimentos são necessários para realizá-la. Contemporaneamente, chega-se mesmo a se falar de uma inclinação totalitária, como já bem o demonstrou Emmanuel Lévinas em Totalité et infini. Para a filosofia blondeliana, a atitude orientada para o ponto de vista do todo - ainda que chamado de "totalidade" da ação -

\footnotetext{
${ }^{63}$ BLONDEL, Maurice. "Le point de départ de la recherche Philosophique" (1906). In: Ouvres Complètes II, 1888-1913. La philosophie de L'Action et la crise moderniste. Paris: PUF, 1997a, p. 550.

${ }^{64}$ BLONDEL, Maurice. "Le point de départ de la recherche Philosophique" (1906). In: Ouvres Complètes II, 1888-1913. La philosophie de L'Action et la crise moderniste. Paris: PUF, 1997 a, p. 550.

${ }^{65}$ Sobre a importância que a noção de "atitude" ganhará na Action, sendo um termo utilizado para dizer a integração entre reflexão e prospecção, são interessantes as observações de Álvaro Pimentel: "Uma atitude é uma complexa síntese em ação, vivida e pensada, entrelaçando desejos, ideais e decisões. Mas ela é expressa muitas vezes segundo pretensões desmedidas" (A "Lógica da Ação" de Maurice Blondel: explicitação crítica na Ação (1893). Belo Horizonte: UFMG, 2008, p. 28 (Tese de doutorado) [Disponível em: http://www.bibliotecadigital.ufmg. br/dspace/handle/1843/ARBZ-7G5K29. Acesso: 01/11/2016]).

${ }^{66}$ BLONDEL, Maurice. "Le point de départ de la recherche Philosophique" (1906). In: Ouvres Complètes II, 1888-1913. La philosophie de L'Action et la crise moderniste. Paris: PUF, 1997a, p. 551.
} 
não se confunde com o conceito de totalidade de Lévinas, antes com o seu de infinito, porque a ação não é a ideia da ação. Em suma, a assunção da atitude que admite como tarefa da filosofia a crescente integração entre prospecção e reflexão, sem as tratar como procedimentos isolados, mas também sem confundi-las, é o caminho identificado pela filosofia da ação para justificar a filosofia.

Apesar de tudo isso, porém, não é ilícita a pergunta sobre se essa atitude seria bem-sucedida. A integração entre prospecção e reflexão como tarefa da filosofia é verdadeiramente realizável, é verdadeiramente inteligível? Como satisfazer suas condições, ou seja, sem as isolar ou sacrificar uma à outra, integrar em um mesmo conhecimento prospecção e reflexão? Seria uma pergunta ainda a ser respondida, mas devemos deixá-la para outra ocasião.

\section{Referências:}

ARISTOTELES. Metafisica. Eddizione maggiore rinnovata, saggio introduttivo, testo greco con traduzione a fronte e commentario a cura di Giovanni Reale. Milano: Vita e Pensiero, 1995.

ARISTÓTELES. Tópicos. In : ARISTÓTELES. Órganon. 2ª ed. Bauru: Edipro, 2010, p. 347-543.

BLONDEL, Maurice. L'Action: essai d'une critique de la vie et d'une science de la pratique (1893). Paris: Quadrige 1993 (Reedição da edição original de 1950 da PUF).

BLONDEL, Maurice. "Le point de départ de la recherche Philosophique" (1906). In: Ouvres Complètes II, 1888-1913. La philosophie de L'Action et la crise moderniste. Paris: PUF, 1997a, p. 527-569.

BLONDEL, Maurice. “L'Illusion idéaliste” (1898). In: Ouvres Completes II, 1888-1913. La philosophie de L'Action et la crise moderniste. Paris: PUF, 1997b, p. 197-216.

BLONDEL, Maurice. "Principe élémentaire d'une logique de la vie morale" (1900 publicado em 1903). In: Ouvres complètes II: 1888-1913. La philosophie de L'Action et la crise moderniste. Paris: PUF, 1997c, p. 365-385.

BLONDEL, Maurice. “Une des sources de la pensée moderne l'évolution du spinozisme" (1894). In: Oeuvres complètes II: 1888-1913. La philosophie de L'Action et la crise moderniste. Paris: PUF, 1997d, p. 57-88.

BRUNSCHVIGC, Léon. "L'idéalisme contemporain". In: BLONDEL, Maurice. "Participation au premier congrès international de philosophie" (1900). In: Ouvres complètes II: 1888-1913. La philosophie de L'Action et la crise moderniste. Paris: PUF, 1997e, pp. 311-318.

D'AGOSTINI, Franca. Breve Storia della Filosofia nel Novecento: L'anomalia Paradigmatica. Torino: Einaudi, 1999. 
HEGEL, Georg Wilhelm Friedrich. Fenomenologia do Espírito. 2ª ed. Petrópolis: Vozes, 2011.

KANT, Immanuel. Critica della Ragione Pratica. 3aㅗ ed., Roma/Bari: Laterza, 2001a.

KANT, Immanuel. Crítica da Razão Pura. 5 $5^{\mathbf{a}}$ ed., Lisboa: Fundação Calouste Gulbekian, $2001 b$.

LALAND, André (Org.). Vocabulaiere téchnique et critique de la philosophie (19021923). Paris, PUF, 1926. Tradução portuguesa de Fátima Sá Correia, Maria Ermínia Aguiar, José Eduardo Torres e Maria Gorete de Souza: Vocabulário Técnico e Crítico da Filosofia. São Paulo: Martins Fontes, 1999.

LÉVINAS, Emmanuel. Totalité et infini. Essai sur l'exteriorité. The Hage, Martinus Nijhoff Publishers, 1971. Traduzione italiana di Adriano Dell'Asta: LÉVINAS, Emmanuel. Totalità ed Infinito. saggio sull'esteriorità. Milano, Jacka Book, 2000.

PIMENTEL, Álvaro. A "Lógica da Ação" de Maurice Blondel: explicitação crítica na Ação (1893). Belo Horizonte: UFMG, 2008. (Tese de doutorado) [Disponível em: http://www.bibliotecadigital.ufmg.br/dspace/handle/1843/ARBZ-7G5K29. Acesso: 01/11/2016].

PLATÃO. A República. 12ª ed., Lisboa: Fundação Calouste Gulbenkian, 2010.

PUNTEL. Lorenz B. A totalidade do Ser, O Absoluto e o tema "Deus": um capítulo de uma nova metafísica. In: IMAGUIRE, Guido; ALMEIDA, Custódio Luís S. de; OLIVEIRA, Manfredo Araújo de (Org.). Metafísica contemporânea. Petrópolis, Vozes, 2007, p. $191-222$.

Endereço do Autor:

Av. Dom Adelino Dantas, 58

59300-000 Caicó - RN

galileumed@yahoo.com.br 